\title{
Effect of Sowing Method and Seeding Rate on Yield and Yield Components of Rainfed Rice (Oryza sativa L.) Varieties in Woliso, South-West Shoa Zone, Ethiopia
}

\author{
Delessa Angassa \\ Ethiopian Biodiversity Institute, Addis Ababa, Ethiopia
}

Email address:

delessan_2006@yahoo.com

\section{To cite this article:}

Delessa Angassa. Effect of Sowing Method and Seeding Rate on Yield and Yield Components of Rainfed Rice (Oryza sativa L.) Varieties in Woliso, South-West Shoa Zone, Ethiopia. International Journal of Applied Agricultural Sciences. Vol. 3, No. 5, 2017, pp. 104-110. doi: $10.11648 /$ j.ijaas.20170305.11

Received: June 15, 2017; Accepted: July 14, 2017; Published: August 16, 2017

\begin{abstract}
A field experiment was conducted on a farmer's field in Woliso District of Oromia Region to determine the effect of sowing method and seeding rate on growth, yield components and yield of rice varieties under rainfed conditions. Factorial combinations of three varieties (X-jigna, Gumera and Superica-1), two sowing methods (broadcast and row planting) and three seeding rates (75, 100 and $125 \mathrm{~kg} / \mathrm{ha}$ ) were laid out in Randomized Complete Block Design with three replications. Analysis of variance showed significantly higher difference among varieties for productive tillers, higher grain yield and total biomass. Significantly higher number of tillers at maturity and productive tillers $/ 0.5 \mathrm{~m}^{2}$ as well as higher grain yield and total biomass $/ 0.5 \mathrm{~m}^{2}$ were produced by Gumera. On the other hand, significantly greater grain yield/ha was produced by Gumera than that of Superica-1 and X-jigna. The effect of sowing method was non-significant on the growth parameters, yield and yield components of rice plants. Significantly greater grain yield/ha was obtained at seeding rate of $100 \mathrm{~kg} / \mathrm{ha}$ than 75 and 125 $\mathrm{kg} / \mathrm{ha}$. Hence, based on this experimentation, Gumera at seeding rate of $100 \mathrm{~kg} / \mathrm{ha}$ with broadcasting or row planting method recommended for Woliso areas.
\end{abstract}

Keywords: Variety, Seeding Rate, Sowing Method, Rainfed Rice, Yield

\section{Introduction}

Rice (Oryzasativa L.) is the world's third largest crop after maize and wheat. It is the staple food for more than half of the world population. Rice cultivation is the principal activity and source of income for about 100 million households and its demand will continue to expand due to population growth and increasing consumption patterns in different regions [FAO, 2004].

Evidences have indicated that cultivation of the crop in Ethiopia was first started at Fogera and Gambella plains in the early 1970's. Recently, rice is cultivated in Fogera plains, Pawe, the Northern part of Ethiopia and Gambella in Western part of Ethiopia on small scale [MoARD, 2005].

In South-West ShoaZone of Oromia Region, a vast area of land is waterlogged in summer especially during July and August. Hence, low infiltration and drainage problems hamper soil management and production of most arable crops. Therefore, the major crop production constraints in the area include water logging and low use of improved agricultural technologies.

In order to make the use of such huge area of potentially cultivable land, rice was introduced in the Zone in 1970's in Teji areas by Koreans. However, the adoption of the crop by the farming communities was impeded in Zone, as well as, across the Region due to poor recognition of the potential of the crop for the flooded and waterlogged areas, lack of knowhow to produce the crop, the absence of sustained and intensified research and improved packages and practices for production.

Therefore, to harness the potential and develop optimal production packages, intensive studies need to be made on cultural practices of rice production in Woliso areas in particular and in the Oromia Region in general. Among key cultural practices, the determination of sowing method and seeding rate for rice varieties (X-jigna and Gumera, and 
Superica-1) are required to be worked out on the priority basis.

Thus, the objectives of this study were to determine effect of sowing method and seeding rate on yield and yield components of rice varieties under rain-fed conditions, to determine the interacting effects of sowing method, seeding rate and variety on yield and yield components of rice in the target area and to suggest optimal production practices for relatively adapted rice variety (ies) in Woliso.

\section{Materials and Methods}

\subsection{Description of the Study Area}

The experiment was conducted on a farmer's field during the main rainy season at Goro in Woliso District of Oromia Region. Geographically, the experimental site is located at $8^{0}$ $21^{\prime} \mathrm{N}$ latitude and $37^{\circ} 47^{\prime} \mathrm{E}$ longitude and at an elevation of 1820 m.a.s.l. According to [NMA, 2006], the total rain fall during 2006 cropping season is $1344.9 \mathrm{~mm}$. The major portion of the total annual rainfall received is between June and September. The total rainfall received between these months in the 2006 cropping season was $841.4 \mathrm{~mm}$ which was $62.5 \%$ of the total rainfall in the year. The average yearly minimum and maximum temperatures were $12.9^{\circ} \mathrm{C}$ and $25.0^{\circ} \mathrm{C}$, respectively. The rain for the main growing season usually commences in the beginning of June and terminates in end-September. The soil of the experimental site was Vertisol.

\subsection{Experimental Details}

Factorial combinations of three rice varieties (X-jigna, Gumera and Superica-1), two sowing method (broadcast and row) and three seeding rates $(75,100$ and $125 \mathrm{~kg} / \mathrm{ha})$ were laid out in a randomized complete block design (RCBD) with three replications.

Each plot received uniform doses of $69 \mathrm{~kg} \mathrm{~N} / \mathrm{ha}$ and $20 \mathrm{~kg}$ $\mathrm{P} /$ ha using urea $(46 \% \mathrm{~N})$ and di-ammonium phosphate $(18 \%$ $\mathrm{N}$ and $20 \% \mathrm{P}$ ) fertilizers. Nitrogen was applied in two equal splits, at planting and at panicle initiation stage; whereas full dose of $\mathrm{P}$ was applied at planting.

The gross plot size was $4 \mathrm{~m} \times 2.5 \mathrm{~m}\left(10 \mathrm{~m}^{2}\right)$. Each plot accommodated 10 rows of $4 \mathrm{~m}$ length in row planted plots. The outer most rows or $0.25 \mathrm{~m}$ width at both sides of plots and $0.5 \mathrm{~m}$ length at both ends of plots were considered as borders. The second and third rows at one side of each plot or $0.5 \mathrm{~m}$ width were designated as sampling area and fourth row or $0.25 \mathrm{~m}$ width served as guard for sampling areas. The net plot size was $1.25 \mathrm{~m} \mathrm{x} 3 \mathrm{~m}$ (constituting the remaining five rows of $3 \mathrm{~m}$ length in row planted plots) for determination of grain yield. The distance between plots and blocks was $0.5 \mathrm{~m}$ and $1 \mathrm{~m}$ apart, respectively.

\subsection{Data Collection}

At $90 \%$ physiological maturity, number of tillers (productive, non productive and total) $/ 0.5 \mathrm{~m}^{2}$ were counted using $0.5 \mathrm{~m} \times 0.5 \mathrm{~m}$ quadrat from two random locations of the sampling area. Number of spikelets/panicle was determined from randomly sampled 20 panicles from each plot.

Thousand-grain weight was recorded by counting 1000 grains of representative seeds samples collected from each plot. It was also adjusted to $12 \%$ moisture content and weighed using an electronic balance. At physiological maturity, plants were hand harvested close to the ground level.

Grain yield $/ 0.5 \mathrm{~m}^{2}$ and above ground total biomass yield $/ 0.5 \mathrm{~m}^{2}$ were determinedusing $0.5 \mathrm{~m} \times 0.5 \mathrm{~m}$ quadrat from two random locations of sampling area. Harvest index was determined as ratio of grains to above ground total biomass $/ 0.5 \mathrm{~m}^{2}$. Crop of entire net plot area was harvested to determine grain yield, straw yield and total biomass yield and converted to $\mathrm{kg} / \mathrm{ha}$ basis. Grain yield was adjusted to $12 \%$ moisture content and straw yield/ha was determined after sun drying for 3 weeks to bring moisture content to near minimum level.

\subsection{Statistical Analysis}

All data were subjected to analysis of variance (ANOVA) to evaluate the effect of treatments and their interaction [Gomez and Gomez, 1984] by using MSTAT-C software program. Significant differences between and/or among treatments were carried out using LSD at 5\%or $1 \%$ level of significance.

\section{Results and Discussion}

\subsection{Yield Components}

The yield components viz. number of panicles per unit area, number of spiklets per panicle, percentage of ripened grains per panicle and thousand grain weight were determined. Among yield components, productive tillers are very important because the final yield is mainly a function of the number of panicles bearing tillers per unit area and number of grains per panicle [Chatterjee and Maiti, 1985].

Number of tillers, productive and unproductive tillers/ 0.5 $m^{2}$ at $90 \%$ maturity

The main effects of variety and seeding rate were significant $(\mathrm{P} \leq 0.01)$ in affecting the number of tillers, productive and unproductive tillers (Table 1). Gumera produced significantly greater number of tillers than X-jigna and Superica-. Furthermore, higher number of tillers was produced by variety $\mathrm{X}$-jigna as compared to that of Superica1. Varietal differences in number of tillers were also reported by [Wilson and McClung, 1998] and [Lafarge et al., 2004]. Significantly greater number of productive tillers was recorded in Gumera than X-jigna and Superica-1. X-jigna and Superica-1 produced statistically similar number of panices $/ 0.5 \mathrm{~m}^{2}$. On the other hand, significantly higher number of unproductive tillers was observed on Gumera and $\mathrm{X}$-jigna varieties. Gumera and X-jigna produced comparable unproductive tillers.

Regarding the seeding rate, seeding rate of $100 \mathrm{~kg} / \mathrm{ha}$ was 
produced significantly higher number of tillers than at other two seeding rates. Furthermore, 75 and $125 \mathrm{~kg} /$ ha produced comparable number of tillers.

On the other hand, seeding rates of 100 and $125 \mathrm{~kg} / \mathrm{ha}$ produced significantly greater number of productive tillers $/ 0.5 \mathrm{~m}^{2}$ as compared to the lowest $75 \mathrm{~kg} / \mathrm{ha}$ of seeding rate. At Seeding rates of 100 and $125 \mathrm{~kg} / \mathrm{ha}$ the numbers of productive tillers $/ 0.5 \mathrm{~m}^{2}$ were comparable with each other. On the contrary, higher number of unproductive tillers were recorded at seeding rates of 100 and $75 \mathrm{~kg} / \mathrm{ha}$ than $125 \mathrm{~kg} / \mathrm{ha}$ (Table 1). The number of unproductive tillers was significantly decreased at the highest seeding rate of 125 $\mathrm{kg} / \mathrm{ha}$ as compared to the other seeding rates. Greater increase in the number of unproductive tillers at 75 and 100 $\mathrm{kg} / \mathrm{ha}$, whereas, the proportion of number of unproductive tillers to productive tillers $/ 0.5 \mathrm{~m}^{2}$ was quite low at seeding rate of $125 \mathrm{~kg} / \mathrm{ha}$. As a result, $125 \mathrm{~kg} / \mathrm{ha}$ seeding rate recorded greater number of productive tillers $/ 0.5 \mathrm{~m}^{2}$. [Yamada, 1961] also showed that under dense planting, the growth of each plant decreases and the size of the plants and productive tillers become smaller. The more densely the rice plants, fewer are the number of stems or tillers and productive tillers per hill but their number increases per unit area. The interaction effects of variety $\mathrm{x}$ sowing method, variety $\mathrm{x}$ seeding rate were not significant to affect the number of tillers, productive and unproductive tillers/ $0.5 \mathrm{~m}^{2}$ at $90 \%$ maturity of rice (Table 2 ).

Number of spikelets per panicle

The number of spikelets per panicle was significantly affected by the main effect of variety and seeding rate (Table 1). Significantly higher number of spikelets per panicle was produced by X-jigna than Superica-1 and Gumera. Furthermore, higher spikelets/panicle was produced by Superica-1 as compared to Gumera. Also difference in spikelet numbers between varieties was reported by [Shiratsuchil et al., 2004].

Regarding seeding rate, 75 and $100 \mathrm{Kg} / \mathrm{ha}$ significantly produced greater number of spikelets per panicle than 125
$\mathrm{Kg} / \mathrm{ha}$. On the other hand, 75 and $100 \mathrm{~kg} / \mathrm{ha}$ showed statistically similar number of spikelets/panicle (Table 1). Similar to these results, [Balocket al., 2002] who reported that the increased plant spacing considerably resulted in vigorous plant growth and caused a significant increase in number of panicles per hill, grain yield per hill, filled grain per panicle and thousand grain weights. Furthermore, several other workers [Mosalemet al., 2000] in other crop reported that increasing seeding rates decreased the number of spikelets/panicle, spike length, number and weight of grains/spike in wheat. [Jaama, 1998] also reported that due to reduced spike length, fewer spikelets/spike and kernels/spikelet of triticale were observed with increased seeding rate or plant density.

On the other hand, main effect of sowing method showed non significant effect on number of spikeletes per panicle. Likewise, the interaction effects were not significant (Table 2).

Table 1. Effect of variety, sowing method and seeding rate onnumber of tillers at $90 \%$ physiological maturity (NTM), number of productive tillers (NPT), number of unproductive tillers (NUT) and number of spikelets per panicle (NSP).

\begin{tabular}{lllll}
\hline Treatment & $\mathbf{N T M} / \mathbf{0 . 5 m ^ { 2 }}$ & $\mathbf{N P T} / \mathbf{0 . 5 m ^ { 2 }}$ & $\mathbf{N U T} / \mathbf{0 . 5 m ^ { 2 }}$ & NSP \\
\hline Variety & & & & \\
X-jigna & 196.7 & 163.8 & 32.8 & 96.2 \\
Gumera & 283.3 & 247.9 & 35.2 & 72.6 \\
Superica-1 & 172.9 & 151.2 & 21.7 & 79.8 \\
LSD $_{0.05}$ & 13.76 & 13.29 & 3.90 & 5.43 \\
Sowing method & & & & \\
Broad cast & 214.9 & 186.0 & 28.9 & 82.5 \\
Row planting & 220.4 & 189.3 & 30.9 & 83.2 \\
LSD 0.05 & NS & NS & NS & NS \\
Seed rate (Kg/ha) & & & & \\
75 & 208.7 & 173.3 & 35.2 & 88.3 \\
100 & 227.1 & 194.6 & 32.5 & 84.5 \\
125 & 217.1 & 195.1 & 22.0 & 75.8 \\
LSD $_{0.05}$ & 13.76 & 13.29 & 3.90 & 5.43 \\
C. V., $\%$ & 9.29 & 10.41 & 19.20 & 9.63 \\
\hline
\end{tabular}

NS: non significant

Table 2. Analysis of variance for number of tillers at $90 \%$ physiological maturity, number of productive tillers, number of unproductive tillers andnumber of spikelets per panicle.

\begin{tabular}{|c|c|c|c|c|c|}
\hline \multicolumn{6}{|c|}{ Mean squares } \\
\hline Source of variation & df & $\begin{array}{l}\text { NTM } \\
/ 0.5 \mathrm{~m}^{2} \\
\end{array}$ & $\begin{array}{l}\text { Number of } \\
\text { productive tillers } / 0.5 \mathrm{~m}^{2}\end{array}$ & $\begin{array}{l}\text { Number of } \\
\text { Unproductive tillers } / 0.5 \mathrm{~m}^{2}\end{array}$ & $\begin{array}{l}\text { Number of } \\
\text { spikelets/panicle }\end{array}$ \\
\hline Replication & 2 & $152.89 \mathrm{NS}$ & $420.02 \mathrm{NS}$ & $75.10 \mathrm{NS}$ & $122.08 \mathrm{NS}$ \\
\hline Variety (V) & 2 & $60757.72 * *$ & $49706.46 * *$ & $937.17 * *$ & $2632.55 * *$ \\
\hline Sowing method (SM) & 1 & $411.13 \mathrm{NS}$ & $153.35 \mathrm{NS}$ & $54.00 \mathrm{NS}$ & $5.95 \mathrm{NS}$ \\
\hline VXMS & 2 & $807.46 \mathrm{NS}$ & $889.13 \mathrm{NS}$ & $3.50 \mathrm{NS}$ & $144.85 \mathrm{NS}$ \\
\hline Seeding rate(S) & 2 & $1525.06^{*}$ & $2789.24 * *$ & $872.17 * *$ & $742.68 * *$ \\
\hline V X S & 4 & $77.11 \mathrm{NS}$ & $118.19 \mathrm{NS}$ & $16.92 \mathrm{NS}$ & $149.17 \mathrm{NS}$ \\
\hline MS X S & 2 & $34.57 \mathrm{NS}$ & $79.69 \mathrm{NS}$ & $10.50 \mathrm{NS}$ & $51.55 \mathrm{NS}$ \\
\hline V X MS X S & 4 & $272.57 \mathrm{NS}$ & $224.80 \mathrm{NS}$ & $4.25 \mathrm{NS}$ & $19.17 \mathrm{NS}$ \\
\hline Error & 34 & 408.40 & 381.53 & 32.94 & 63.60 \\
\hline
\end{tabular}

$* *, *$ significant at $1 \%$ and $5 \%$ levels, respectively

$\mathrm{NS}=$ non significant

$\mathrm{df}=$ degree of freedom

There was significant variation in thousand grain weight among varieties (Table 1). Variety Superica-1 produced significantly greater thousand seed weight than X-jigna and Gumera. On the other hand, Gumera and X-jigna showed 
similar thousand grain weights (Table 3 ).

The main effect of sowing method had no significant effect on thousand grain weight. Broadcast and row planting sowing method showed comparable thousand grain weight. Similarly, the main effect of seeding rate was not significant in affecting thousand grain weights. But there was a decreasing trend in thousand grain weight as the seeding rate was increased from 75 to $125 \mathrm{~kg} / \mathrm{ha}$. In conformity with these results, [Jan et al., 2000] who conducted an experiment on wheat reported that as the seeding rate was increased, the number of plants emerged per unit area also increased but thousand seed weight decreased. [Lockhart and Wiseman, 1988] also revealed that higher number of tillers reduced the number, size and weight of grains. Further, [Wen and Yang, 1991] reported higher thousand-grain weight by planting one seedling/hill than with four seedlings/ hill.

Grain yield per $0.5 \mathrm{~m}^{2}$

Statistical analysis of data showed highly significant difference $(\mathrm{P} \leq 0.01)$ due to the main effect of variety on grain yield of rice $/ 0.5 \mathrm{~m}^{2}$ (Table 3 ). Gumera produced significantly higher grain yield $/ 0.5 \mathrm{~m}^{2}$ than Superica -1 and $\mathrm{X}$-jigna. Furthermore, Superica-1 yielded significantly higher grain yield $/ 0.5 \mathrm{~m}^{2}$ than $\mathrm{X}$-jigna. Varietal differences in grain yield were also reported by [Yoshida and Parao, 1972] and they indicated that a variety of different tillering capacity and of improved type, yielded better than of low tillering one. Furthermore, it was also supported by [Fukai, 2000]; [Balock et al., 2002]; [Bughio et al., 2002]; [Reddy et al., 2004].

The main effect of seeding rate was significant $(\mathrm{P} \leq 0.05)$ in affecting the grain yield of rice crop and higher grain yield $/ 0.5 \mathrm{~m}^{2}$ was obtained at the rate of $100 \mathrm{Kg} / \mathrm{ha}$ than 125 and 75 $\mathrm{Kg} / \mathrm{ha}$. Seeding rates of 75 and $125 \mathrm{~kg} /$ ha produced comparable grain yield $/ 0.5 \mathrm{~m}^{2}$ (Table 4). [Balock et al., 2002] indicated that wider spacing had linearly increasing effect on the performance of individual plants. The plants grown with wider spacing have more area of land around them to draw the nutrition and had more solar radiation to absorb for better photosynthetic process and hence performed better as individual plants. The reason for deviation in case of grain yield per plot is that the grain yield does not entirely depend on the performance of individual plant but also on the total number of plants per plot and yield contributing parameters within the plant.

The main effect of sowing method and the interaction effects of variety $\mathrm{x}$ sowing method, variety $\mathrm{x}$ seeding rate, sowing method $\mathrm{x}$ seeding rate and variety $\mathrm{x}$ sowing method $\mathrm{x}$ seeding rate were not significant to affect the grain yield of rice (Table 4).

Total biomass per $0.5 \mathrm{~m}^{2}$

Total biomass was significantly $(\mathrm{P} \leq 0.01)$ affected by the main effect of variety only (Table 3 ). Gumera produced higher total biomass yieldthan X-jigna and Superica-. Such a high total biomass yield was obtained as a result of high capacity of tillering of the variety and vigorous growth of the tillers. Furthermore, X-jigna produced significantly higher total biomass than the Superica-1.
Main effects of sowing method and seeding rate as well as the interaction effect of variety $\mathrm{x}$ sowing method, variety $\mathrm{x}$ seeding rate, sowing method $\mathrm{x}$ seeding rate and variety $\mathrm{x}$ sowing method $\mathrm{x}$ seeding rate were not significant in affecting the total biomass yield of rice (Table 4).

Harvest index

Harvest index represents the ratio of the dry matter of harvested part of the crop (grain yield) to the total dry matter production [Marschener, 1995]. The main effect of variety significantly affected the harvest index $/ 0.5 \mathrm{~m}^{2}$ (Table 3). Analysed data revealed that Gumera and Superica-1 had significantly higher harvest index (40.51\%) and (39.5\%) than $\mathrm{X}$-jigna $(30.30 \%)$. On the other hand, Gumera and Superica-1 exhibited comparable harvest index. Significant varietal differences in harvest index have also been reported by [Evans et al., 1984]; [Stapper and Fischer, 1990]; [Brain, 2005].

The main effect of sowing method resulted in nonsignificant variation in harvest index. Similarly, the main effect of seeding rate was not significant for harvest index $/ 0.5 \mathrm{~m}^{2}$ and there was a trend of increasing harvest index as seeding rate increased from 75 to $100 \mathrm{~kg} / \mathrm{ha}$ but at a seeding rate of $125 \mathrm{~kg} / \mathrm{ha}$, the harvest index was decreased. These findings are in agreement with results obtained by [Brain, 2005] who reported that the effect of seeding rate was not significant for harvest index. Further, [Zeng and Shannon, 2000] showed that at high density, carbohydrate supply was limited because of shading among plants and the competition between shoot growth and panicle growth. This resulted in the reduction in harvest index with the increases in seeding densities. The interaction effect of variety $\mathrm{x}$ sowing method, variety $\mathrm{x}$ seeding rate, sowing method $\mathrm{x}$ seeding rate and variety $\mathrm{x}$ sowing method $\mathrm{x}$ seeding rate were not significant to affect the grain yield of rice (Table 4).

Table 3. Effect of variety, sowing method and seeding rate effects on thousand grain weight, grain yield, total biomass and harvest index.

\begin{tabular}{|c|c|c|c|c|}
\hline Treatment & $\begin{array}{l}\text { Thousand } \\
\text { Grain } \\
\text { weight(g) }\end{array}$ & $\begin{array}{l}\text { Grain } \\
\text { yield } \\
(\mathrm{g}) / 0.5 \mathrm{~m}^{2}\end{array}$ & $\begin{array}{l}\text { Total biomass } \\
\text { (g)/ } 0.5 \mathrm{~m}^{2}\end{array}$ & $\begin{array}{l}\text { Harvest } \\
\text { index } \\
(\%)\end{array}$ \\
\hline \multicolumn{5}{|l|}{ Variety } \\
\hline $\mathrm{X}$-jigna & 26.17 & 148.72 & 472.83 & 31.5 \\
\hline Gumera & 25.94 & 240.89 & 555.33 & 43.4 \\
\hline Superica-1 & 32.06 & 180.39 & 428.06 & 42.1 \\
\hline $\operatorname{LSD}_{0.05}$ & 0.22 & 17.44 & 43.10 & 1.43 \\
\hline \multicolumn{5}{|l|}{ Sowing method } \\
\hline Broad cast & 28.00 & 183.15 & 471.15 & 38.9 \\
\hline Row planting & 28.11 & 196.85 & 500.33 & 39.3 \\
\hline $\mathrm{LSD}_{0.05}$ & NS & NS & NS & NS \\
\hline \multicolumn{5}{|c|}{ Seeding rate $(\mathrm{Kg} / \mathrm{ha})$} \\
\hline 75 & 28.11 & 184.61 & 480.06 & 38.5 \\
\hline 100 & 28.10 & 203.50 & 510.00 & 39.9 \\
\hline 125 & 27.94 & 181.89 & 468.61 & 38.8 \\
\hline $\mathrm{LSD}_{0.05}$ & NS & 17.44 & NS & NS \\
\hline C. V., $\%$ & 1.21 & 13.93 & 13.05 & 5.71 \\
\hline
\end{tabular}

NS: non significant 
Table 4. Analysis of variance for thousand grain weight, grain yield, total biomass, harvest index.

\begin{tabular}{llllll}
\hline Source of variation & df & $\begin{array}{l}\text { Thousand } \\
\text { Grain weight } \mathbf{( g )}\end{array}$ & $\begin{array}{l}\mathbf{G r a i n} \text { yield } \\
\mathbf{g} / \mathbf{0 . 5} \mathbf{m}^{\mathbf{2}}\end{array}$ & $\begin{array}{l}\text { Total biomass } \\
\mathbf{g} / \mathbf{0 . 5} \mathbf{m}^{\mathbf{2}}\end{array}$ & $\begin{array}{l}\text { Harvest index } \\
\mathbf{( \% )} / \mathbf{0 . 5} \mathbf{m}^{\mathbf{2}}\end{array}$ \\
\hline Replication & 2 & $0.39 \mathrm{NS}$ & $1927.72 \mathrm{NS}$ & $8290.30 \mathrm{NS}$ & $7.46 \mathrm{NS}$ \\
Variety (V) & 2 & $216.22^{* *}$ & $39473.17^{* *}$ & $74006.46 * *$ & $553.35^{* *}$ \\
Sowing method (SM) & 1 & $0.17 \mathrm{NS}$ & $2535.19 \mathrm{NS}$ & $11498.96 \mathrm{NS}$ & $4.92 \mathrm{NS}$ \\
VXMS & 2 & $0.22 \mathrm{NS}$ & $1764.13 \mathrm{NS}$ & $9800.35 \mathrm{NS}$ & $1.43 \mathrm{NS}$ \\
Seeding rate( S) & 2 & $0.17 \mathrm{NS}$ & $2493.72^{*}$ & $7616.35 \mathrm{NS}$ & $5.68 \mathrm{NS}$ \\
V X S & 4 & $0.06 \mathrm{NS}$ & $806.64 \mathrm{NS}$ & $6463.35 \mathrm{NS}$ & $1.20 \mathrm{NS}$ \\
MS X S & 2 & $0.06 \mathrm{NS}$ & $1037.57 \mathrm{NS}$ & $2135.91 \mathrm{NS}$ & $0.03 \mathrm{NS}$ \\
V X MS X S & 4 & $0.11 \mathrm{NS}$ & $179.94 \mathrm{NS}$ & $5018.80 \mathrm{NS}$ & $0.03 \mathrm{NS}$ \\
Error & 34 & 0.114 & 700.47 & 4017.00 & 4.40 \\
\hline
\end{tabular}

$* *, *=$ significant at $1 \%$ and $5 \%$ levels, respectively

$\mathrm{NS}=$ non significant

$\mathrm{df}=$ degree of freedom

\subsection{Yield}

\section{Grain yield per hectare}

Grain yield was significantly $(\mathrm{P} \leq 0.01)$ affected by the main effects of variety and seeding rate (Table 5). Higher grain yield/ha was produced by Gumera than Superica-1 and $\mathrm{X}$-jignaas it produced greater dry weight, number of tillers and productive tillers due to its higher tillering ability. Varietal differences for grain yield were also reported by [Fukai, 2000]; [Balock et al., 2002]; [Bughio et al., 2002]; [Reddy et al., 2004].

On the other hand, at seeding rate of $100 \mathrm{~kg} / \mathrm{ha}$, significantly higher grain yield was obtained than at 75 and $125 \mathrm{~kg} /$ ha (Table 5). Furthermore, seeding rates of 75 and $125 \mathrm{~kg} /$ ha produced comparable grain yield/ha. At the seeding rate of $100 \mathrm{~kg} / \mathrm{ha}$, the grain yield/ha was increased by $506 \mathrm{~kg} / \mathrm{ha}(22.2 \%)$ and $561 \mathrm{~kg} / \mathrm{ha}(25.2 \%)$ as compared to 75 and $125 \mathrm{~kg} / \mathrm{ha}$, respectively. The present findings are not in agreement with that of [Sewunet, 2005] where higher grain yield was obtained at a seeding rate of $120 \mathrm{~kg} / \mathrm{ha}$ than 60,80 and $100 \mathrm{~kg} / \mathrm{ha}$ seeding rates with X-jigna variety in Fogera areas, South Gonder of Amhara Region, Ethiopia.

Grain yield of rice increased with the increase in the number of plants per unit area as long as there is space in the cultivated areas. When planting density exceeds an optimum level, competition among plants for light above ground and for nutrients below ground becomes severe. Consequently, plant growth slow and grain yield decreases. Similar results were reported by [Zeng and Shannon, 2000] who reported that the reduction in fertility at high density was one of the causes for the reduction of seed yield per plant with the increase of seeding density.

The main effect of sowing method was not significant in influencing the grain yield of rice (Table 5). The present study is in agreement with results obtained by [Dhurandher et al., 2000] who reported that line sowing and broadcasting produced similar effect on productivity and profit of rice crop. [Klosterboer and Turner, 2002] also reported that there is no yield difference among the row drilled and broadcast seeding if the stands are adequate.

The interaction effects of variety $x$ sowing method, variety $\mathrm{x}$ seeding rate, sowing method $\mathrm{x}$ seeding rate and variety $\mathrm{x}$ sowing method $\mathrm{x}$ seeding rate had no significant effect on grain yield of rice (Table 6).

Straw yield per hectare

Statistical analysis of data showed significant differences in straw yield due to the main effect of variety (Table 5). Maximum straw yield/ha was obtained in Gumera and Xjigna than Superica-1. Furthermore, X-jigna and Gumera showed statistically similar straw yield/ha.

The main effect of sowing method and seeding rate were not significant in influencing straw yield/ha of rice crop. Broadcast and row planting sowing method produced comparable straw yield/ha. On the other hand, there was a trend of increment in straw yield/ha as the seeding rate increased from $75 \mathrm{~kg} / \mathrm{ha}$ to $100 \mathrm{~kg} / \mathrm{ha}$. But at the seeding rate of $125 \mathrm{~kg} / \mathrm{ha}$, the straw yield decreased which was less as compared to $75 \mathrm{~kg} / \mathrm{ha}$ seeding rate. [Balock et al., 2002] showed that straw yield increased with increased spacing in transplanted rice.

The interaction effects of variety $\mathrm{x}$ sowing method, variety $\mathrm{x}$ seeding rate, sowing method $\mathrm{x}$ seeding rate and variety $\mathrm{x}$ sowing method $\mathrm{x}$ seeding rate had no significant effect on straw yield/hectare (Table 6).

\section{Total biomass yield per hectare}

The main effect of variety was significant in affecting total biomass yield (Table 5). Gumera produced significantly $(\mathrm{P} \leq 0.01)$ higher total biomass than $\mathrm{X}$-jigna and Superica-1. Furthermore, Superica 1 and X-jigna produced comparable total biomass yield.

The main effects of sowing method had non-significant effect on total biomass yield. Similarly, the main effect of seeding rate was non-significant in influencing variation on total biomass yield/ha. [Kanada and Kakizaki, 1957] observed a logarithmic relationship between plant population and production of total dry weight per unit area. [Yamada, 1961] reported that the total dry matter and grain weight per unit area increased with decrease in spacing up to a certain extent after which, there was no change or decrease depending on the character of the variety. This is in other way, implied that higher planting density within limit might produce more total dry matter per unit area. The interaction effects of variety $x$ sowing method, variety $\mathrm{x}$ seeding rate, sowing method $\mathrm{x}$ seeding rate and variety $x$ sowing method $x$ seeding rate were not statistically significant effect in affecting total biomass 
yield per hectare of rice crop (Table 6).

Table 5. Effect of variety, sowing method and seeding rate effects on grain, straw and total biomass yield $(\mathrm{kg} / \mathrm{ha})$.

\begin{tabular}{llll}
\hline & & Yield (kg/ha) & Total biomass \\
\hline Treatment & Grain & Straw & 6182.00 \\
\hline Variety & 1823 & & 7359.00 \\
X-jigna & 3264 & 4450.44 & 5792.80 \\
Gumera & 2200 & 3592.80 & 652.30 \\
Superica-1 & 265.7 & 384.0 & 6484.22 \\
LSD 0.05 & & & 6642.00 \\
Sowing method & 2329 & 4155.22 & NS \\
Broad cast & 2529 & 4113.00 & 6294.50 \\
Row planting & $\mathrm{NS}$ & $\mathrm{NS}$ & 6840.50 \\
LSD 0.05 & & & 6187.30 \\
Seeding rate $(\mathrm{Kg} / \mathrm{ha})$ & 2279 & 4015.50 & $\mathrm{NS}$ \\
75 & 2785 & 4055.50 & 14.32 \\
100 & 2224 & 3963.30 & $\mathrm{NS}$ \\
125 & 265.7 & 13.65 & \\
LSD $_{0.05}$ & 16.07 & & \\
C. V.,\% & & & \\
\hline
\end{tabular}

NS: not significant

Table 6. Analysis of variance for grain yield, strawyield and total biomass yield.

\begin{tabular}{lllll}
\hline & & & Mean squares \\
\hline Source of variation & df & $\begin{array}{l}\text { Grain yield } \\
\text { Kg/ha }\end{array}$ & $\begin{array}{l}\text { Straw yield } \\
\text { Kg/ha }\end{array}$ & $\begin{array}{l}\text { Total biomass yield } \\
\text { Kg/ha }\end{array}$ \\
\hline Replication & 2 & $357258.30 \mathrm{NS}$ & $205092.13 \mathrm{NS}$ & $1674997.85 \mathrm{NS}$ \\
Variety (V) & 2 & $10049452.35 * *$ & $3992610.80 * *$ & $15472331.13 * *$ \\
Sowing method (SM) & 1 & $537802.24 \mathrm{NS}$ & $24108.91 \mathrm{NS}$ & $2379720.30 \mathrm{NS}$ \\
VXMS & 2 & $6310.57 \mathrm{NS}$ & $989610.69 \mathrm{NS}$ & $2907965.57 \mathrm{NS}$ \\
Seeding rate( S) & 2 & $1719623.19 * *$ & $414706.96 \mathrm{NS}$ & $2090112.96 \mathrm{NS}$ \\
V X S & 4 & $204844.10 \mathrm{NS}$ & $231859.88 \mathrm{NS}$ & $326947.44 \mathrm{NS}$ \\
MS X S & 2 & $660237.85 \mathrm{NS}$ & $391470.30 \mathrm{NS}$ & $1027092.07 \mathrm{NS}$ \\
V X MS X S & 4 & $85565.60 \mathrm{NS}$ & $72977.16 \mathrm{NS}$ & $209549.44 \mathrm{NS}$ \\
Error & 34 & 152322.81 & 318367.13 & 918431.28 \\
\hline
\end{tabular}

**** = significant at $1 \%$ and $5 \%$ levels, respectively

$\mathrm{NS}=$ non significant

$\mathrm{df}=$ degree of freedom

\section{Conclusions}

The study was conducted to determine the effect of sowing method and seeding rate on growth, yield and yield components of three rice varieties under rainfed conditions.

The results showed that significant differences in grain yield and most of parameters of rice were observed due to variety and seeding rates; especially in case of Gumera which yielded maximum yield at seeding rate of $100 \mathrm{~kg} / \mathrm{ha}$. On the other hand, sowing method had significant difference on crop phenology but had no effect on growth parameters, yield and yield components of rice crop under Woliso conditions. Hence, Gumera variety planted at a seeding rate of $100 \mathrm{~kg} / \mathrm{ha}$ with either broadcasting or row planting method in Woliso area. But more information will be needed on more levels of individual factors, years and different production practices so that agronomic recommendations to the farmers can be generated on available cultivars for maximum production.

\section{Acknowledgements}

The author expresses his deepest gratitude to staff of Sasakawa Global 2000, Ethiopia as a whole for their utmost cooperation in every possible ways. In particular, the guidance and support of Dr. Tareke Berhe and

Mr. Zewdie Gebretsadik is gratefully acknowledged for their consistent professional advice, field supervision and for providing references and materials.

The author sincerely thanks Oromia Agricultural Research Institute of Fitche Soil Laboratory Research Centre for soil analysis and oven drying of the experimental samples. A special thanks is also extended to Mr. Tilahun Legese for his advice, encouragement and support of field materials especially during the final field work. 


\section{References}

[1] Balock, A. W., A. M. Soomro, M. A. Javed, M. Ahimed, H. R. Bughio, M. S. Bughio and N. N. Mastoi, 2002. Optimum plant density for high yield in rice (Oryza sativa L.). Asian Journal of Plant Sciences. 1(1): 25-27.

[2] Brain, V. O., 2005. Rice yield components as affected by Cultivar and Seeding rate, University of Missouri Columbia, Delta Research Centre, Columbia.

[3] Bughio, H. R., A. M. Soomro, A. W. Baloch, M. A. Javed, I. A. Khan, M. S. Bughio, T. Mohammad and N. N. Mastoi, 2002. Yield potential of aromatic rice mutants (varieties) in different ecological zone of Sindh. Asian Journal of Plant Sciences. 1(4): 439-440.

[4] Chatterjee, B. N. and S. Maiti, 1985. Principles and practices of rice growing, $2^{\text {nd }}$ ed., Oxford and IBH publishing Co. Bombay, New Delhi. 1-77pp.

[5] Dhurandher, R. L., P. Khanna, and R. S. Tripathi, 2000. Response of early rice cultivar to method of seeding and $\mathrm{N}$ levels under agrecological situation of Eastern Madhya Pradesh. Crop Research, India. 20(3): 367-371.

[6] Evans, L. T., R. M. Visperas and B. S. Vergara, 1984. Morphological and physiological changes among rice varieties used in the Philipines over the last seventy years. Field Crop Research. 8: 105-125.

[7] FAO, 2004. Rice and Us. Food and Agricultural Organization of the United Nations, Rome, Italy.

[8] Fukai, S., 2000. Rice cultivars requirements for direct seeding in rainfed lowlands. In: Pendey, S., M. Mortimer, L. Wada, T. P. Toung, K. Lopez and B. Hardey (eds.). Direct seeding research strategies and opportunities, Proceedings of a Workshop, 25-28 January, Bankok, Thailand.

[9] Gomez, A. K. and A. A. Gomez, 1984. Statistical Procedures for Agricultural Research with emphasis on Rice. IRRI, Los Bonas, Philippines.

[10] Jaama, E., P. Kaearu, A. Vooremae and U. Laur, 1998. Influence of nitrogen fertilization and sowing rates on the yield of winter triticale in Estonia. In: Proceedings of the $4^{\text {th }}$ International Triticale Symposium, 26-31 July, Alberta, Canada 2: 324-330.

[11] Jan, A., I. Hamid and T. J. Muhammad, 2002. Yield and yield component of wheat as influenced by seeding rates and sowing dates. Pakistan Journal of Biological Science 3(2): 323-325.

[12] Kanada, M. and Y. Kakizaki, 1957. Studies on the spacing density of rice plants. I., Density effects on yield and interspecific competition. Tohoku University. Institute of Agricultural Research Report. 8(2): 107-126.

[13] Klosterboer, A. D. and F. T. Turner, 2002. Rice production guidelines. Texas Cooperative Extension, USA.

[14] Lafarge, T., B. Tubana and E. Pasuquin, 2004. Yield advantage of hybrid rice induced by its higher control in tiller emergence.
In: proceedings of the $4^{\text {th }}$ International Crop Science Congress. Brisbane, Australia.

[15] Lockhart, J. A. R., and A. J. L. Wiseman, 1988. Introduction to Crop Husbandry. Oxford, UK: Wheaton\& Co. Ltd., Pergamon Press. 70-180pp.

[16] Marschner, H., 1995. Mineral nutrition of higher plants. $2^{\text {nd }}$ ed. Academic press, London. 783p. MoARD, 2005. Crop variety register, Ministry of Agriculture and Rural Development, Crop Development Department, Addis Ababa, Ethiopia.

[17] Mosalem, M. E., M. Zahran, M. M. El-Menofi and A. M. Moussa, 2002. Effect of sowing methods and seeding rates on growth and yield of some wheat cultivars. In: Proceedings of the $5^{\text {th }}$ International Triticale Symposium, June 30-July 5, Radizikow, Poland 2: 239-392.

[18] NMA, 2006. Woliso Meteorological Station of rainfall and temperature data of 1997-2006. National Meteorological Agency. Addis Ababa, Ethiopia.

[19] Reddy, C. V., R. K. Malik and Y. Ashok, 2004. Performance of rice cultivars under different resource conservation techniques. In: Proceedings of the $4^{\text {th }}$ International crop Science Congress. Brisbane, Australia.

[20] Sewunet Ashebir, 2005. Effect of nitrogen and seeding rates on grin yield, yield components and Nitrogen uptake of Rainfed Rice (Oryzasativa L) in Fogera, South Gonder. M. Sc. Thesis Presented to the School of Graduate Studies of Alemaya University.

[21] Shiratsuchil, H., Y. Ohdaira and J. Takanashi, 2004. Relationship of dry weight and spikelet number of each tiller at heading in rice plants. In: proceedings of the $4^{\text {th }}$ International Crop Science Congress 26 September-10 October, Brisbane, Australia.

[22] Stapper, M. and R. A. Fischer, 1990. Genotype, sowing date and plant spacing influence on high yielding irrigated wheat in Southern New South Wales. II. Growth, yield and Nitrogen use. Australian Journal of Agricultural Research. 41(6): 10211041.

[23] Wen, H. N. and Z. G. Yang, 1991. Studies of the cultivation method with transplanting single seedlings per hill in late rice. Zhejiang Nongye Kexue. 6: 264-268.

[24] Wilson, G. L. and A. M. McClung, 1998. Contribution of rice tillers to dry matter accumulation and yield. Agronomy Journal. 90(3): 317-323.

[25] Yamada, N., 1961. On the relationship between yield and spacing in rice. Agricultural and Horticultural. 36(1): 13-18.

[26] Yoshida, S. N. and F. T. Parao, 1972. Performance of improved rice varieties in the tropics with special reference to tillering capacity. Agricultural Experiment. 8: 203-213.

[27] Zeng, L. and M. C. Shannon, 2000. Effects of Salinity on Grain Yield and Yield Components of Rice at Different Seeding Densities. Agronomy Journal. 92: 418-423. 